\title{
Molecular Characterization of Pythium Spp. Isolated from Tomato Seedlings in the Syrian Coast
}

\author{
Mohamad Imad Khreibeh ${ }^{1,2}$, Wafaa Choumane ${ }^{2,3}$, Ibtissam Ghazal ${ }^{2}$ and Fawaz Azmeh ${ }^{1,4}$ \\ 1. National Center for Biotechnology (NCBT), Damascus, Syria \\ 2. Faculty of Agriculture, Tishreen University, Lattakia, Syria \\ 3. Biotechnology Centre at Tishreen University, Lattakia, Syria. \\ 4. Plant Protection Department, Faculty of Agriculture, Damascus University, Syria, Expert at NCBT
}

\begin{abstract}
Tomato seedlings damping-off is a limiting factor in commercial greenhouse production. To determine the causal agents of disease, sampling and fungal isolation were performed during 2012. Samples were collected from infected seedlings growing in greenhouses in the Syrian coastal region. Isolation of fungi was done in the laboratories of the Agronomical Reaserch Center, in Lattakia and the molecular analyses were done in the Biotechnology Center at Tishreen University, Lattakia, Syria, during the years 2012, 2013. Eight isolates of Pythium sp. obtained were purified using hyphal tip method (named P1, P2, P3, P4, P5, P6, P7 and P8). Isolates were morphologically identified by optical microscope, then molecularly Characterized using genus specific ITS primers. The results of morphological characterization of pathogenic species suggested the detection of Pythium aphanidermatum, P. ultimum. The analysis of DNAs from the different isolates with ITS primers, recognizing the inter transcript spacer of nuclear ribosomal DNA proved that the eight, isolates were belonging to the species P. ultimum. The complete sequences of ribosomal DNA internal transcribed spacers regions of selected isolates were determined and submitted to GenBank. The GenBank-BLAST homology search revealed P. ultimum as the most similar sequence ( $>96 \%$ identity) with GenBank entry AB355596.
\end{abstract}

Key words: Tomato, Pythium sp., Polymerase Chain Reaction (PCR), ITS.

\section{Introduction}

Tomato (Lycopersicon esculentum Mill.) ranks as the leading fresh and processed vegetable crop in Syria and many other countries in the world. The number of greenhouses are approximately 67,977 (Statistical Abstract of Syrian Agriculture, 2012). It is grown practically all over the world in open fields, greenhouses and net-houses. However, tomato is a host for several pathogens including fungi, fungal like organisms, bacteria, viruses and nematodes. The environmental conditions that are favored to tomato (especially in greenhouse which always has high humidity and moderate to high temperature) enhance the conditions for the growth of specific soil-borne pathogens including the two fungal genus Pythium

Corresponding author: Mohammad Imad Khrieba, Ph.D., research field: plant pathology and biological control. E-mail: imadkhrieba@gmail.com. and Phytophthora (Kerkeni et al., 2007; Akaza et al., 2009). Pythium causes seed rot, damping-off and root rot which are the most destructive and economically important agricultural problems worldwide in nursery and greenhouse crops (Agrios, 2005). Pythium species are widely distributed in the world, and they are the major pathogens causing damping-off of seeds and seedlings (Kageyama and Nelson, 2003). The most important species of genus pythium sp. are prevailing in Syria and causing damping-off of tomato seedlings.

Pythium aphanidermatum (Edson) Fitzp, pythium ultimum Trow (Al-Shaabi et al., 2007). Seeds infected with this fungal pathogen typically won't germinate and will decompose. Young seedlings may topple over and their stems develop mushy lesions. Water-soaked lesions appear on fruits infected with Pythium spp. and infected tissues such as stems and roots will begin to darken and become soft before 
rotting. Another symptom of Pythium and root rot is a white mycelial growth with a cotton-like appearance forming on infected plant tissue. Some infected tomato plants may have stunted growth while others show few symptoms above ground (Agrios, 2005). The genus Pythium is belonging to the family of Pythiaceae, order Perenosporales, class Oomycetes, phylum Heterokonta (Dick, 2001). More than 200 species of this genus have been described (Paul et al., 1999). Historically, species identification of this genus was mainly based on morphological characteristics including the size and shape of oogonia, antheridia and sporangia on Corn Meal Agar CMA (Shahzad et al., 1990). The traditional identification brought about obscure delimitation between some species because they had few variable morphological characteristics or lost their ability to produce sexual structures (Levesque and Cock, 2004). In recent years, the morphological characterization has been supplemented by molecular characteristics of given species (Paul, 2004). Morphology-based taxonomy is increasingly being supplemented by molecular characteristics of a given species (Paul, 2004). The recent advent of molecular biology has contributed to the diagnosis of plant pathogenic fungi by offering new revolutionary methods for quicker and more accurate detection, identification and quantification. Fungi can be identified at the species level by primers designed on selected conserved sequences like the rRNA gene cluster followed by further characterization of the amplified fragment. The rRNA gene cluster became very popular for a number of reasons; it has several hundred copies per genome and it carries highly conserved and variable regions. Sequences of the rRNA subunits have been used for taxonomic and genetic studies, while conserved regions of the internal transcribed spacers (ITS) and the intergenic spacers (IGS) have been targeted for fungal detection (Paplomatas, 2006). Traditionally, the most prevalent techniques used to identify plant pathogens have relied upon culture-based morphological approaches. These methods, however, are often time-consuming, laborious, and require extensive knowledge of classical taxonomy. Other limitations include the difficulty of some species to be cultured in vitro, and the inability to accurately quantify the pathogen (Goud and Termorshuizen, 2003). These limitations have led to the development of molecular methods with improved accuracy and reliability. A high variety of molecular methods have been used to detect, identify and quantify a long list of plant pathogenic fungi. Molecular methods have also been applied to study the genetic variability of pathogen populations, and even to describe new fungal species. In general, these methods are faster, more specific, more sensitive, and more accurate, and can be performed and interpreted by personnel with no specialized taxonomical expertise (Levesque and Cock, 2004). The PCR for the amplification of the ribosomal gene has been used for the genetic identification of many organisms because it comprises both highly conserved sequences during evolution and highly variable sequences among species and even within species. Plenty of studies on molecular phylogeny among Pythium species and even within Pythium species have been conducted (Schurko et al., 2003; Lévesque and de Cock 2004) Molecular phylogenies based on the ITS region have been recently produced for the genus Pythium (Matsumoto et al., 1999; Levesque and de Cock, 2004). The Internal Transcribed Spacer (ITS) region of the rRNA gene sequences has become a useful tool for Pythium taxonomy, and it can also be used for identifying or detecting different Pythium spp. (Paul, 2000, Levesque and de Cock, 2004).

\section{Material and Methods}

\subsection{Morphological Identification}

Infected seedlings were collected from many tomato greenhouses in the Syrian coastal regions. Preliminary identification of fungi species in the eight different cultures was done using morphological 
Characters of spores. Morphological Characters showed that the eight isolates belong to the two species: Pythium aphanidermatum (Edson) Fitzp, pythium ultimum Trow (Khrieba et al., 2013).

\subsection{Molecular Identification}

\subsubsection{DNA isolation}

Eight isolates (P1, P2, P3, P4, P5, P6, P7 and P8) were sub-cultured on vegetable juice medium (V8). Each isolate was sampled and inoculated in $25 \mathrm{ml}$ of V8 containing $2.5 \mathrm{~g}$ of $\mathrm{CaCO}_{3}$, then incubated in a shaker incubator at $28{ }^{\circ} \mathrm{C}$ with speed of $120 \mathrm{rpm}$ for ten days. After ten days of incubation under darkness at $28{ }^{\circ} \mathrm{C}$, the fungal mycelium from the eight isolates were harvested and dried on absorbent paper. DNA was extracted from mycelium using CTAB protocol. (Benito et al. 1993).

2.2.2 DNA amplification by Polymerase chain reaction (PCR)

DNAs of different isolates were analyzed using Opmycete ITS primers. The primer pair ITS1/ITS4 [ITS1 (5'-TCC GTA GGT GAA CCT GCG G-3') and ITS4 (5'-TCC TCC GCT TAT TGA TAT GC-3')] and primer pair ITS6/ITS4 [ITS6 (5'-GAA GGT GAA GAA GTC GTA GTA ACA AGG-3') and ITS4 (5'-TCC TCC GCT TAT TGA TAT GC-3')] were used to distinguish the isolates of Pythium genus (White et al., 1990) where it amplifies a single band of 900 bp (Cooke et al., 2000). The specific primer pair puk1/puk2 [(Puk1 F: '5ACGAAGGTTGGTCTGTTG-3') and (OOMS-lo 5.8 47 B R: '5- TCTTGTCTGATATCAGGTCg-3')] were used to differentiate isolate belonging to P. ultimum, while the specific primer pair P18GAA1-71/P18GAA1-71 amplify a specific product in $P$. aphanidermatum (Lee and Moorman, 2008). The specific primer pair P18GAA1-71/P18GAA1-71 [(P18GAA1-71 F: '5-CGCATTACGTATCGCAGTTCGCAG-3') and (P18GAA1-71 R: '5ATtCAGTTTATCACAGCGACGA-3')]. The PCR reaction was performed in $20 \mu \mathrm{L}$ containing $20 \mathrm{ng}$ of DNA $(4 \mu \mathrm{L}), 2 \mu \mathrm{l}$ of each primer $(100 \mu \mathrm{M}), 10 \mu \mathrm{L}$ GoTaq Green Master Mix (Promega BioSciences, LLC, San Luis Obispo, CA, USA), $4 \mu \mathrm{L}$ of H2O. Amplification was performed in an eppendorph thermal cycler. The PCR program started by an Initial denaturation at $95{ }^{\circ} \mathrm{C}$ for $4 \mathrm{~min}$, followed by 35 cycles, each of them is composed of a denaturation step at 95 ${ }^{\circ} \mathrm{C}$ for $1 \mathrm{~min}$, annealing step at $55^{\circ} \mathrm{C}$ for $1 \mathrm{~min}$, and an extension step at $72{ }^{\circ} \mathrm{C}$ for $70 \mathrm{sec}$. and one cycle for a final extension step at $72{ }^{\circ} \mathrm{C}$ for $5 \mathrm{~min}$. The amplified products were separated on $1.2 \%$ agarose gels in a $1 \mathrm{X}$ TBE buffer. Gels were stained ethidium bromide and were photographed under UV light.

\subsubsection{Sequencing PCR products}

Direct sequencing of the PCR products was done by the DNA sequencing laboratory of Biotechnology in National Center for Biotechnology (NCBT). The complete rDNA ITS regions were sequenced in both directions using the primers ITS1 and ITS4. DNA sequence data obtained in this study has been deposited in GenBank. DNA sequences were compared to homologous sequences registered in GenBank using the standard nucleotide-nucleotide BLAST protocol (http://www.ncbi.nlm.nih.gov/BLAST/).

\section{Results and Discussion}

\subsection{Molecular Characterization}

3.1.1 Amplification and characterization of the rDNA ITS sequences

PCR amplification of the rDNA ITS region of Pythium isolates using the ITS6-ITS4 primer pairs was successful and gave PCR products of 900 base pair (bp). Use of the primers ITS1 and ITS4: $910 \mathrm{bp}$ showed that all isolates belong to the genus pythium sp. (Fig. 1). Amplification of the target P. ultimum DNA was done using the specific primers Pukland puk2 band and gave approximately 670 bp. But, amplification of the P. aphanidermatum DNA was done using the specific primer pair P18GAA1-71F 
and P18GAA1-71R, giving no bands (Fig. 2)

The rDNA ITS nucleotide sequences of those isolates showed high sequence homology $(>96 \%$ identity) (Fig. 3). The GenBank-BLAST homology search using these ITS sequences revealed $P$. ultimum as the most similar sequence ( $>96 \%$ identity) with GenBank, and thus show that the eight isolates belong to $P$. ultimum.

\section{Discussion}

The identification of most Pythium species is difficult due to overlapping of morphological characteristics, as clearly illustrated in the Venn-diagram taxonomic key of Dick (1990). Moreover, cultural conditions can influence the variability of morphological characteristics and lead to misidentification of species (Kageyama et al., 2005). The result of failure could be in identification of some characters of Pythium. Therefore, phylogenetic relationship based on molecular identification was used to determine the real name of the pathogenic fungi. Because of reliance of many recent phylogenetic analyses on sequences of the internal transcribed spacer ribosomal DNA (ITS rDNA) region, the DNA sequence database in GenBank is comprehensive, and sequencing has become a powerful tool for identification (Lévesque and de Cock 2004, Matsumoto et al 1999, Villa et al 2006). At present, amplification of DNA sequence by primers ITS5 and ITS4 is similar to the results that always produce a single band approximately $900 \mathrm{bp}$ as obtained Cooke et al. (Cooke et al. 2000). Target DNA consisted of small subunit (SSU) 18S partial sequence, the ITS1, ITS2, 5.8S rDNA complete sequence, and large subunit (LSU) 28S rDNA partial sequence (Matsuda et al, 2005). Molecular biology has impacted more and more heavily on mycology (Borman et al, 2008). Species identification based on phenotypic identification is often time-consuming, requiring high attention by researchers, having high error probability (Siricord, 2005) and is readily influenced by cultural conditions (Borman et al, 2008). Conversely, molecular phylogenetic identification involving

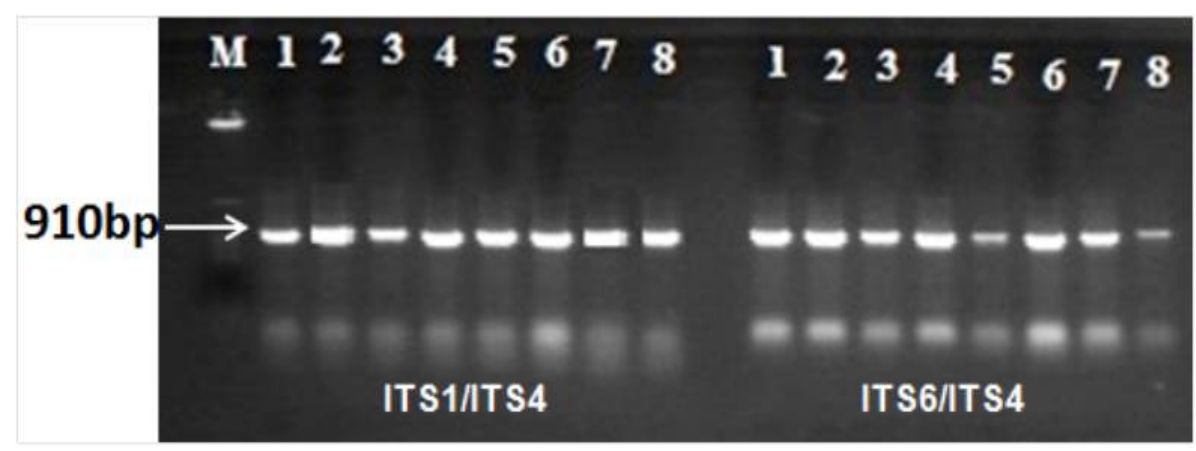

Fig. 1 Extracted DNA of Pythium sp was amplified with primer pairs ITS 1 and 4, ITS 4 and 6, and M is a marker (GeneRuler'M DNA Ladder Mix 100).

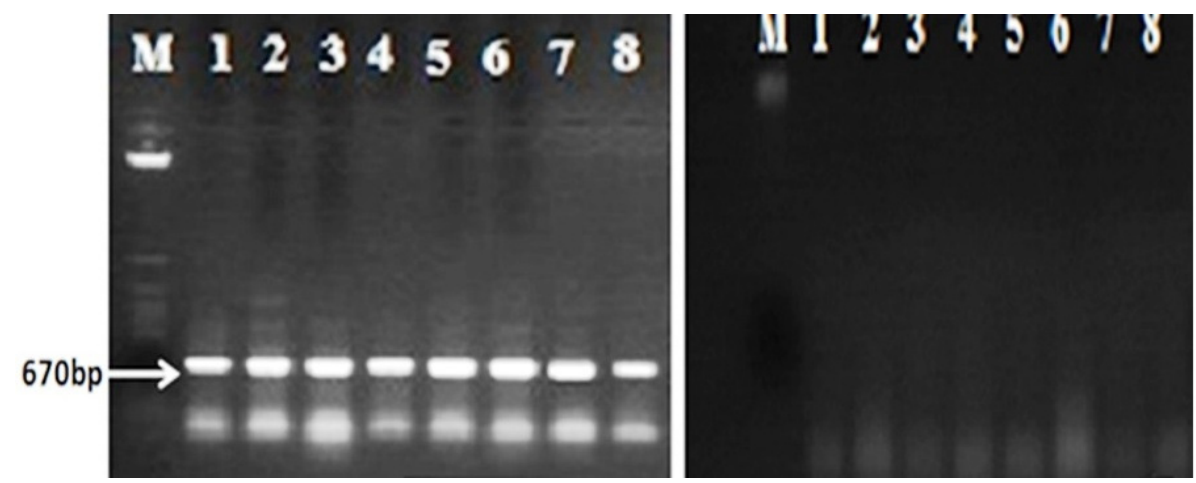

Fig. 2 Amplification of the target $P$. aphanidermatum DNA was done using the specific primers P18GAA1-71F, P18GAA1-71R (1). (2) Amplification of the target P. ultimum DNA was done using the specific primers Puk1and puk2. 


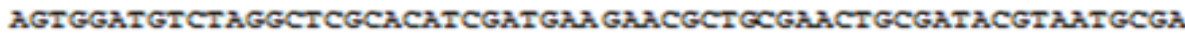

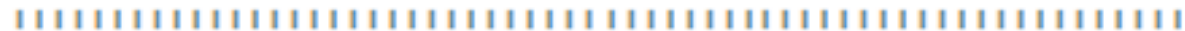

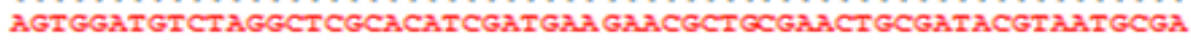

AITGCAGAגTCAGIGAGTCATCGAגATITIGAACGCATATTGCACITICGGGIIATGCC 111111111111111111111111111111111111111111111111111111111111 ATTGCAGAATTCAGIGAGTCATCGAAATTIGAACGCATATTGCACTITCGGGTIATGCC

ICCACGIGAACIGTAAGCAAGICIAGCGCIGIGACIGAGCIGGIGIIITCATITITGGAC 111111111111111111111111111111111111111111111111111111111111 ICCACGTGAACTGTAAGCAAGTCTAGCGCI GTGACIGAGCTGGTGTTITCATITITGGAC

ACTGGAhCGGGAGTCAGCAGGACGAhGGITGGTCTGITGTARTGCAגGITATGATGGACT

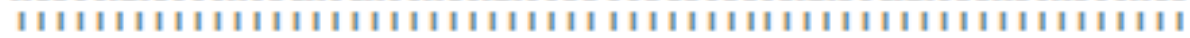
ACTGGAACGGGAGICAGCAGGACGAגGGII GGICTGITGTAATGCAAGTTATGATGGACT

AGCTGATGAACITITGITITAAגCCCITACCTAגATACTGATITATACTGIGGGGACGA 111111111111111111111111111111111111111111111111111111111 AGCIGATGAACITIIGITITIAAACCCITACCIAAATACTGATITATACTGIGGGGACGA

IAGGCIICGGCICGACAAIGIIGCGIAATIGIGIGIGGICIIIGIIIGIGCCIIGAGGIG

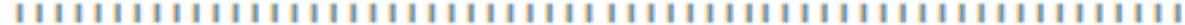
TAGGCTICGGCICGACAATGTIGCGIAATIGIGTGIGGICITTGITIGTGCCTIGAGGTG

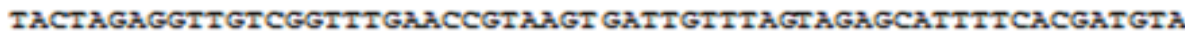
1111111111111111111111111111111111111111111111111111111111 IACTAGAGGITGICGGITGAACCGIAAGI GAITGIITGIAGAGCAIITICACGATGIA

IICGATCGAGAגTCIGIC--GICCIIIIAAגIGGACCCGGICIIIICIATGGIIICIATG $11111111111111111 \quad 11111111111111111111111111111111111111$ ITCGATCGAGAATCTGICGAGICCTITIAAATGGACACGGICITITCTATGGITICTATG

cIAGCGCIGIGACIGA-CIGGIGIIITGIAGICAIIIITGGACACIGGaACGGGAGICAG $1111111111111111111111110 \quad 1111111111111111111111111111$ CIAGCGCIGIGACIGAGCIGGIGITII-----CATIITIGGACACIGGAACGGGAGTCAG

IICGATCGAGAגTCIGIC--GICCIITIAAגTGGACCCGGICIITICIATGGITICIATG

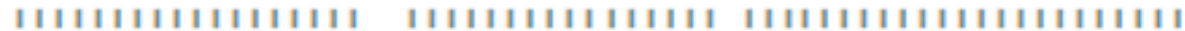
ITCGATCGAGAATCIGICGAGICCIITIAAATGGACACGGICIITICTATGGITICTATG

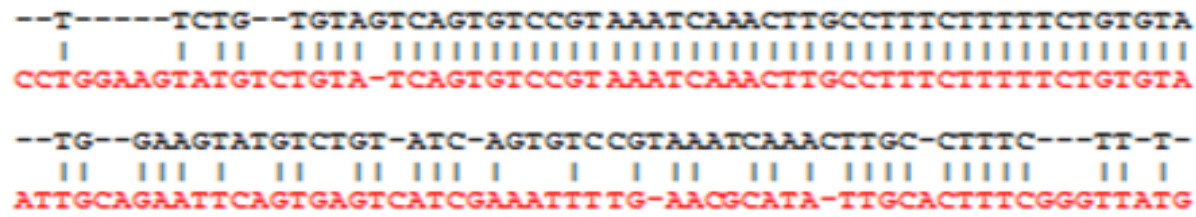

Fig. 3 Nucleotide sequences to one of the isolates fungus Pythium ultimum (top) with isolation AB355596 (bottom) recorded in the gene bank.

gene sequencing is more objective, uninfluenced by growth conditions, and capable of discriminating between fungi that fail to produce distinctive morphological features (Borman et al, 2008).

\section{Conclusions}

The pathogenic species identified based on morphological characterization were close to Pythium aphanidermatum, $P$. ultimum var. ultimum, and $P$. paroecandrum. Their pathogenicity was evaluated on tomato seedlings under greenhouse conditions. All isolates were pathogenic. This is the first report on occurrence of Pythium species causing seedlings damping off in greenhouses in the coastal region. Molecular methods have been used to analyze ITS region of the nuclear ribosomal DNA. Moreover, molecular characterization using Polymerase Chain Reaction (PCR) showed that the eight isolates belong to the species $P$. ultimum.

\section{Acknowledgments}

Thanks to the staff in the Plant Pathology 
Laboratory at the Center for Agricultural Research in Latakia.

\section{References}

[1] Agrios, G. N. 2005. "Plant Pathology." Fifth edition. Elsevier Academic press, London U.K.: 922.

[2] Akaza, M. J., Goran, J. A. K. N., Guetta, S. P. A. N., Kebe, B. I., Tahi, G. M., and Sangare, A. 2009. "Resistance to Phytophthora Palmivora (Butler) Butler Assessed on Leaf Discs of Cacao (Theobroma cacao L.) Hybrid Trees." Asian J. Plant Pathol. 3: 106-18.

[3] Al-Chaabi, S., Malloohi, G., and Matrod, L. 2007. "Control of Tomato Seedlings Damping-Off Disease (Rhizoctonia solani Kuhn.) Using Trichoderma koningii Oudem, Flutolanil or Tolclofos Methyl." Arab J. Pl. Prot. 25: 15-27.

[4] Al-Sheikh, H., HMA Abdelzaher 2012. "Materials for Pythium Flora of Saudi Arabia (I) Occurrence, Pathogenicity and Physiology of Reproduction of Pythium Aphanidermatum (Edson) Fitzp. Isolated from North and East Regions of Saudi Arabia." Res. J. Microbiol. 7: 82-100.

[5] Baptist, F. R., Pires-Zottarelli, C. L. A., Rocha, and Milanez, M. A. I. 2004. "The Genus Pythium Pringshiem from Brazilian Cerrado Areas, in the State of Sao Paulo." Brazil Botanical 27: 281-90.

[6] Benito, C., Figueira, A. M., Zaragoza, C., Gallego, F. J., and de la pena, A. 1993. "Rapid Identification of Triticeae Genotypes from Single Seeds using the Polymerase Chain Reaction." Plant Molecular Biology 21: 181-3.

[7] Borman, A. M., Linton, C. J., Miles, S. J., and Johnson, E. M. 2008. "Molecular Identification of Pathogenic Fungi." Journal of Antimicrobial Chemotherapy 1 (61): 7-12.

[8] Cooke, D. E., Drenth, L. A., Duncan, J. M., Wagels, G., Brasier, C. M. 2000. "A Molecular Phylogeny of Phytophthora and Related Oomycetes." Fungal Genetics and Biology 1 (30): 17-32.

[9] Dick, M. W. 1990. Keys to Pythium. Reading, UK: Univ. Reading.

[10] Dick, M. W. 2001. The Peronosporomycetes. The Mycota VII Part A, Systematics and Evolution (McLaughlin DJ, McLaughlin EG \& Lemke PA, eds). Springer Verlag: 39-72.

[11] Goud, J. C., Termorshuizen, A. J. 2003. "Quality of Methods to Quantify Microsclerotia of Verticillium Dahliae in Soil." European Journal of Plant Pathology 6 (109): 523-34.

[12] Kageyama, K., Nakashima, A., Kajihara, Y., Suga, H., and Nelson, E. B. 2005. "Phylogenetic and Morphological Analysis of Pythium Graminicola and
Related Species.” J. Gen. Pl. Path. 71: 174-82.

[13] Kageyama, K., and Nelson, E. B. 2003. "Differential Inactivation of Seed Exudates Stimulation of Pythium ultimum Sporangium Germination by Enterobacter Cloacae Influences Biological Control Efficacy on Different Plant Species." Applied and Environnemental Microbiology: 1114-20.

[14] Kerkeni, A., Daami-Remadi, M., Tarchoun, N., and Khedher, M. B. 2007. "In Vitro and in Vivo Suppression of Pythium Ultimum the Causal Agent of the Cucumber Damping-off by Some Compost Fungi." Asian J. Agric. Res. 1: 50-8.

[15] Lee, S. H., and Moorman, G. W. 2008. "Identification and Characterization of Simple Sequence Repeat Markers for Pythium aphanidermatum, $P$. cryptoirregulare and $P$. irregulare and the Potential Use in Pythium Population Genetics." Curr Genet 53: 81-93.

[16] Levesque, C. A., and de Cock, A. W. 2004. "Molecular Phylogeny and Taxonomy of the Genus Pythium." The British Mycological Society 88: 213-22.

[17] Matheron, M. E., and Mircetich, S. M. 1985. "Influence of Flooding Duration on Development of Phytophthora Root and Crown Rot of Juglans Hindsii and 'Paradox' Walnut Rootstocks." Phytopathology 75: 973-6.

[18] Matsuda, Y., Sameshima, T., Moriura, N., Inoue, K., Nonomura, T., Kakutani, K., Nishimura, H., Kusakari, S., Takamatsu, S., and Toyoda, H. 2005. "Identification of Individual Powdery Mildew Fungi Infecting Leaves and Direct Detection of Gene Expression by Single Conidium Polymerase Chain Reaction." The American Phytopathological Society 10 (95): 1137-43.

[19] Matsumoto, C., Kageyama, K., Suga, H., and Hyakumachi, M. 1999. "Phylogenetic Relationships of Pythium Species Based on ITS and 5.8S Sequences of Ribosomal DNA Mycoscience." 40: 321-31.

[20] Mostowfizadeh-Ghalamfarsa, R., and BANIHASHEMI, Z. 2005. "Identification of Soil Pythium Species in Fars Province of Iran." Iran. J. Sci. Technol. 29: 79-87.

[21] Nugrahani, M. 2011. "Eksplorasi Kapang Antagonis Terhadap Phytophthora sp. Patogen pada Tanaman Apel." Scholar Thesis, Brawijaya University, Malang.

[22] Paplomatas, E. J. 2006. "Molecular Diagnostics of Fungal Pathogens." Arab J. Pl. Prot. 2 (24): 147-58.

[23] Parija, W., and Prabhakar, P. K. 1995. "Evaluation of Lacto-phenol Cotton Blue for Wet Mount Preparation of Feces." J. Clin. Microbiol. 33: 1019-21.

[24] Paul, B., Galland, D., Bhatnagar, T., and Masih, I. 1999. "Pythium Prolatum Isolated from Soil in the Burgundy Region, A New Record for Europe." FEMS Microbiol Lett. 173: 69-75.

[25] Paul, B. 2004. “A New Species of Pythium Isolated from Burgundian Vineyards and Its Antagonism towards 
Botrytis Cinerea, the Causative Agent of the Grey Mould Disease." FEMS Microbiol. Lett. 234: 269-74.

[26] Paul, B. 2000. "ITS1 Region of the rDNA of Pythium Megacarpum sp. Nov., Its Taxonomy and Its Comparison with Related Species." FEMS Microbiol. Lett. 186: $229-33$.

[27] Schurko, A. M., Mendoza, L., Levesque, C. A., Desaulniers, N. L., De Cock, A. W. A. M., and Klassen, G. R. 2003. "A Molecular Phylogeny of Pythium Insidiosum." Mycol. Res. 107: 537-44.

[28] Shahzad, S., Coe, R., Dick, M. W. 1990. "Biometry of Oospores and Oogonia of Pythium (Oomycetes): the Independent Taxonomic Value of Calculated Ratios." Bot. J. Linn. Soc. 108: 143-65.
[29] Siricord, C. C. 2005. "Detection of Phytophthora Spesies by MALDI-TOF Mass Spectrometry." Murdoch University, Perth.

[30] Statistical Abstract of Syrian Agriculture, Ministry of Agriculture and Agrarian Reform. Damascus. Syria. 2012.

[31] Van der Plaats-Niterink, A. J. 1981. "Monograph of the Genus Pythium." Studies in Mycology 21: 1-242.

[32] Vanderpool, C. R. 2000. "Bacterial Chemistry and Structure." http://zoey.med.howard.edu.

[33] Villa, N. O., Kageyama, K., Asano, T., and Suga, H. 2006. "Phylogenetic Relationships of Pythium and Phytophthora Species based on ITS rDNA, Cytochrome Oxidase II and $\beta$-tublin Gene Sequences.” Mycologia 98: 410-22. 